\title{
Learner Autonomy: A Western Hegemony in English Language Teaching to Enhance Students' Learning for Non-Western Cultural Context
}

Sarmila Pokhrel

\begin{abstract}
The paper is concerned about the concept of learner autonomy as a western hegemony in English language teaching to enhance students' learning for non-Western cultural context. The concept of learner autonomy was developed in the Western countries creating independent and autonomous culture for learners to prepare them; learning to learn, however for it got its continuation as an innovative method to the non-Western countries of dependent culture where parents set up the cultural values and norms for children. Such practice of framing the norms for children is regarded against the cultural assumption of learner autonomy which is considered as Western hegemony for non-Western cultural context. Based on the literature and empirical evidences, the paper argues how learner autonomy as a Western hegemony in English language teaching enhances students' learning in diverse cultural contexts of non-Western countries. With the conceptual, theoretical and practical understanding, the paper explores how learner autonomy as a Western hegemony in English language teaching enhances students' learning for non-Western cultural context.
\end{abstract}

Keywords: Learner autonomy, western hegemony, innovative method, cultural context

\section{Introduction}

Learner autonomy, comparatively an innovative and global concept in modern education, has been defined differently by different scholars. It was originated at the University of Nancy in the1970s by the leadership of the influential figure Holec (1981). He proposes learners' ability of taking charge of their own learning. According to him, such ability is developed by the learners themselves in an autonomous learning environment where learners are skillful and responsible for taking charge of their own learning. In the same vein, Dewey (1966) pays attention to the teaching environment to foster child's continuous development in language learning (Benson, 2001). For him, language learning in learning-friendly environment can support learners to learn themselves.

It shows that basic terminology for the concept of learner autonomy is full of diversity. For instance, Dickinson's (1987) learner autonomy is to the learning situation in which individual manifests an attitude of responsibility and self-direction which is difference than Holec's (1981) learner's ability to be responsible for own learning (as cited in Palfreyman \& Smith, 
2003) however the value was given to learners and their learning culture instead of teachers' teaching. These thinkers of learner autonomy in 1970s contribute to shift the perspectives of teaching culture to learning culture creating awareness to the teachers for their teaching methods from teacher-centered to learner-centered in English language learning in the Western countries.

With the extension of value given to the persons or their schooling culture to the children as an independent learner in the society of Western countries prepared autonomous learners. It is thus, the concept of learner autonomy emerged as a realworld social phenomenon due to the contingent historical processes both within the life history of individuals and within the development of societies in the process of modernization (Anderson, 2011). It is meaningful to present the developmental process of autonomy as a linear concept of autonomisation that assumes the progression from heteronomy to autonomy (Schmenk, 2006).

Influence of different methods \& techniques/ Hegemony to learners

\begin{tabular}{|c|c|}
\hline $\begin{array}{c}\text { Dependence } \\
\text { Heteronomy }\end{array}$ & $\begin{array}{c}\text { Influence of different } \\
\text { methods \& techniques / } \\
\text { Hegemony to learners }\end{array}$ \\
\cline { 2 - 2 } & $\begin{array}{c}\text { Autonomisation } \\
\text { Taking over } \\
\text { responsibility }\end{array}$ \\
\hline
\end{tabular}

Figure 1. Progression from heteronomy to autonomy (Schmenk, 2006).

It shows that learner autonomy is a complex multidimensional concept that can be defined in terms of individual and sociocultural context. Such concept of shifting the role of learning to the learners obviously concerned with the autonomous learning culture that best help people to lead autonomous lives (Benson, 2008, as cited in Neupane, 2010) though it demands learners' capacity for action without intervention of others (Blin, 2005). It is because autonomous culture demands personal autonomy that prepares individual for critical reflection being free to choose what to do with one's life (Anderson, 2011). It got its popularity in teaching English language to enhance students' learning in the developed countries where learners were valued as independent personality.

With the pace of time, it obviously extended its arms to the developing countries in English language teaching though there was lack of autonomy friendly culture in teaching English language. Since all areas in schools, societies and countries of nonWestern countries are inclined from the hegemony of Western countries, learner autonomy is also considered as the Western hegemony and it is a genuine concern to discuss its practicality in teaching English language in the non-Western cultural context.

\section{Practice of learner autonomy in English language teaching}

Learner autonomy is obviously a Western concept that demands freedom for learners taking charge of own learning to learn. As it was practiced before four decades in developed countries, it is not out of question to its practicality in the socio-cultural context of non-Western countries in English language teaching to enhance students' learning. It is considered as a global concept in the field of English language teaching because the concept of learner autonomy has been widely referred in the field of English language teaching (Smith, 2008). 
Learner autonomy thus directly focuses on English language learning being independent learner however it is not only confined within a particular method and the perspective of individualism (Little, 1991). It is also considered as a guiding concept that requires different forms of pedagogy and meets with different kinds of restriction according to context (Palfreyman \& Smith 2003). From this perspective, learner autonomy needs the learning friendly cultural context especially for learning English language though it is cross-culturally valid phenomena.

To depict the clear picture of classroom practice of teachers and students in English language teaching, it is meaningful to present the research finding of Pokhrel (2013) who has exposed that English teachers are less motivated to participate students in activities. Due to the practice of teacher centered-teaching method, students wait for teachers to solve problem and they become reluctant to expose them with others using English language even in ELT classroom. It shows that there is lack of integrity in students' schooling, teachers teaching, demand of society and perspectives of contents in ELT. For instance, mother tong has been given emphasis for primary level in policy whereas parents prefer English as the medium of instruction and enroll their children in English school. Teachers and students also prefer English as the medium of instruction with the autonomy of learning. Exploring the perceptions and practice of teachers and students on learner autonomy in university students, Joshi (2011) has exposed that teachers and students are positive in their perceptions on learner autonomy though they have less practice in classroom. It shows that learner autonomy is out of the reach for the classroom practice of teachers and students in English language teaching in Nepalese cultural context that signify the symptom of hegemony in English language teaching.

\section{Learner autonomy as the Western hegemony to the non- Western cultural context}

As learner autonomy was developed in the western countries with their own cultural values, assumption, belief system to make it common for all that has the hegemonic power to influence others. Such power of hegemony lies in its invisibility and is therefore harder to notice and difficult to oppose it (Gramsci, n. d). It shows that hegemony is a process by which dominant groups seek to impose their belief structure on individuals for the purpose of solidifying their power over them (Kincheloe, 2004). It is said that most of our paradigms originated from North America in the 1950s to 1980s, inspired by the empirical phenomena and culture of that time and impose them on the remaining countries. It is not that non-Western countries are well equipped and independent. It is not contextual to adjust all the Western values to non-Western countries as there is contextual difference between the East and the West in terms of philosophies, cultural values and norms (Barkema, Chen, George, Luo, \& Tsui, 2015).

Not only this, the superiority of the European heritage and Western knowledge is now a firmly re-entrenched notion that we might study the knowledge or entertain perspectives of peoples from other cultures, our ideological perspective is quickly fading the way morning star as the sun rises over Fallujah (Kincheloe, 2008). If this is the case, the Sanskrit saying 'paropakar punyaya, papaya para pidana' (do something for others forgetting the self) will be replaced by the saying of Lekhnath Poudyal 'mai khau mai lau, sukha sayala ma moja ma garu, mai hasu mai nachu aru saba marun durbalaharu' (do 
something for the well being of self forgetting others).

In this sense, learner autonomy is also the Western construct developed with modern education giving the priority to the independent individual and became popular phenomena in post modern education in Western countries. It promulgated its arms with the mass education to the non-Western countries too. For instance, individual autonomy in projecting one's own destiny, creation of new knowledge and skills for better living and respect for dignity and egalitarianism are the major implications of postmodern education (Lamichhane \& Wagley, 2008).

There have been various calls to go beyond the Western setting with empirical phenomenon of the East however there is strong application of Western theories (Barkema et al., 2015). For instance, it is a natural process that the privilege and their offspring of person can influence the discourses and makes individuals stop or frozen into position that hegemony them (Fleischer, 2013). Privileges and offspring of Western countries can influence and hegemony to the non-Western countries. They pay less attention to understand their cultural pedagogy and education that takes place outside of formal schooling. Fleischer (2013) further says that without understanding of cultural pedagogy, the role of shaping the individual identity and their life will be faded by the hegemony. If this is the case, practice of learner autonomy to promote learners learning in the non-Western countries is questionable.

\section{Cultural, political, and economic contexts of learners}

"Give me a fish and I eat for a day. Teach me fishing and I eat for a lifetime". This proverb taken from Chinese culture is significant to learner autonomy that expects the learners to be equipped with the required skills to run their life blissfully and quench their need throughout their life. But certain cultural values that state the yardstick for judging the child as the good or bad is the degree of obedience shown his/her parents (Dardjowidjojo, 2001) that can be obstruction to prepare autonomous learner in non-Western countries. Parents set up the norms and children are expected to adhere (Dardjowidjojo, 2001) so that their children can be obedient to follow the cultural trait continuously without any objection.

As we know that the world is full of diverse socially, culturally, politically and economically, obviously then, this Western learner-centered approach based on individualism may not work in nonWestern country's education because there is difference in culture and context of learners where learners are compelled to adhere the parents' fixed values and norms (Dardjowidjojo, 2001; Smith, 2006). There is difference in orientation of parents where learners are not allowed to go outside the wall or they cannot think to go beyond the fixed border (Krishnamurti, 1987). It is of course the reality and styles are also different. If such differences exist, how the Western concept can be adjusted in nonWestern countries. It is not that learnercentered values are not important. This is of course necessary for preparing autonomous learners from the very beginning of life but it comes to question to its implication. Krishnamurti (1987) also does not believe on autonomous cultural context in non-Western countries to prepare creative learners. In his dialogue with the learner he says,

I don't know if you are creativeprobably not because your parents will not allow you to go outside the wall. You are fixed into a mould and there 
you are struck for the rest of your life then such type of conditional minds can never go beyond its own border. (pp. 48-49)

That's why, certain aspect of a learners' cultural background can restrain the promotion of autonomy. Due to the cultural diversity in Asian context, it is important to explore the cultural backgrounds and find the way for adjustment because it can affect on learning of individual learners (Littlewood, 1999; Neupane, 2010). Krishnamurti (1987) also suggests the learner "If you don't revolt against this process, you become like automatic machine functioning without creativity and original thought and there is no meaning of being educated" (p.52). But Smith (2006) highlights the problems to practice learner autonomy in a variety of cultural contexts.

It is thus, we need to recognize the sociocultural perspectives of learning (Palfreyman \& Smith, 2003), learning resources and learners' identity to promote learner autonomy for many Asian learners (Dang, 2010), intelligent of learners. They must be free from all pseudo-religious, social values and cultural trappings to discover the thing that is real for them (Krishnamurti, 1987). For instance, Chinese teachers dominate the students as a result students become passive, dependent on teachers lacking the ability of managing own studies for autonomous learning (Zhung, 2010).

In such practice, teacher is expected to exercise complete authority and students tend to be dependent upon their teachers for learning (Dang, 2010). The purpose of cultural study in learner autonomy is to unpick the traditional tie between culture and nation. As it speaks the culture of classroom or school, these small cultures may be influenced by national value system and they have their own implication for autonomy (Holliday, 1999, as cited in Palfreyman \& Smith, 2003). Littlewood (1999) also informs that the great influence of cultural traditions and the socio-cultural process particular to Asian countries have an impact on learner autonomy. As a result, East Asian student's achievement is often socially motivated rather than individually oriented. This shows that many other cultures have favored more familial and communal relationships over individualism in contrary to what individualism that western cultures have valued (Chang, Scott \& Decker, 2009). Obviously there is somewhat contradiction to the traditional beliefs of relational hierarchy and socio-cultural stimulus between Western and non-Western countries.

It is relevant to present an African saying "A good father does not give his son meat. Instead, he gives him a bow and arrow, and teaches him to hunt" (Kuchah \& Smith, 2011). It is an example of orientation of parents for their children to prepare skillful learners in Africa. They believe that if pupils have learnt how to learn they can go on learning afterwards (West, 1960, as cited in Kuchah \& Smith, 2011). Proposition of training the learners into better thinker and learner from the very beginning of life is deeply culturist vision of superior culture that is impossible to the learners of all other cultural contexts. To use the analogy of sexism, it is like men deciding how the freedom of women should be structured. It is possible for the educators to be learnercentered, in the same way as it is possible for men to be feminist (Holliday, 2005). It is an issue to explore how learner autonomy is thought and applied in teaching and learning activities (Littlewood, 1999) in Asian diverse socio-cultural, political and economic context. 
In policy review, it has emphasized learners to manage own learning (Blin, 2005) however teachers and students are not able to stand in parallel position in Nepalese cultural context (Koirala, 2011) that might be the context to other nonWestern countries. It is said 'Nothing wipes your tears away but your own hands'. It means individual person must be ready for wellbeing of the self but not others that requires skills of self-learning that has not been practiced effectively in non-Western countries. Whereas in Western countries, democracy and political view of autonomy is primarily concerned with the autonomy of individual as it is constituted within social groups. Political questions about the broader principles of autonomy such as students' rights have been transformed into a psychological concern about how to develop strategies for learner autonomy (Holliday, 2005).

Political perspective of learner autonomy involves gaining access to cultural alternatives and power structure developing an articulate voice with competing ideology. It requires the context of the arrangement of ideological position in a specific interaction, relationship and setting (Palfreyman \& Smith, 2003). As the purpose of western education is to develop responsible individuals, society and school support to accomplish their policy of preparing independent learners who are able to think and decide for them while behaving as accountable, moral and unselfish citizens (Blin, 2005). Whereas socio-cultural value of non-Western countries is not autonomy friendly that consider learner autonomy as a laden value from the West (Jones, 1995, as cited in Littlewood, 1999) in which political and economic condition are attached in it.

It is also true that skill of learner is not considered as education as well as the good source of income because knowledge, wisdom and skills are regarded as separate entities in society. Knowledge is linked with liberation after death, skill is linked with livelihood and wisdom is linked with the process. Those who are equipped with skills are not called 'thulo manche' (honorable persons) in the society though they have earned more. But knowledge, skill and wisdom all are integrated in education in Western countries (Koirala, July, 12, 2015 from the discussion with BBC program) which can be the source to be independent whatever they choose in the society.

As a result, it is easier for the learners to be independent in the Western countries in comparison to the non-Western countries. Perhaps it might be the attitude to observe with this lens that there should be rich and poor so that rich can manipulate poor for their own behalf like big fish sustain with the small one. Or there is a cultural practice of respecting the difference in the society. This shows that cultural, political and economic context of non-Western countries need to be considered for the implementation of learner autonomy to promote autonomous learning.

\section{Theoretical standpoint of learner autonomy in ELT}

The notion of learner autonomy in ELT exposes the philosophical assumption of constructivist epistemology in which teachers have to regain their capacity for their students' learning and give them opportunity for decision making being autonomous learner. It comes under the theoretical assumption of post method pedagogy that places a great deal of focus on the autonomy of learners (Kumaravadivelu, 2003). It is because learner-focused lessons not only access higher-order thinking and language skills through the use of problem-solving, inquiry, synthesis of ideas, and inference but also students' background knowledge, 
experience, and cultures as foundational elements of instruction, interaction, and assessment (ibid) that further demands to think beyond the single method (Kumaravadivelu, 2002). It is also necessary to think culturally relevant methods because autonomous culture based method might not be applicable to other diverse cultural context (Walker \& Dimmock, 2000, as cited in Nguyen, Terlouw, \& Pilot, 2006).

It is thus post method pedagogy allow for learners to experiencelearning by actively pursuing, processing and obtaining knowledge. This process of discovery is a key to autonomous learning. It is effective both in convincing the learners of the knowledge they themselves have created, and the validity of it (Knaldre, 2015). The efforts of researchers to the promotion of learner autonomy through the classroomoriented theories and principles toward learner autonomy reached a new level to this era (Benson, 2009).

This shows that learner autonomy has had a complex and multi-faceted development towards its present status as an internationally recognized aspect of foreign language learning. That's why Little (1994, as cited in Bayat, 2008) informs that autonomy is not a single easily described behavior. The process has been driven by socio-cultural changes, shifting psychological paradigms and learning theories. It has some sort of mismatch between theoretical and pedagogical assumptions. It is thus to promote principles of learner autonomy requires not only change in teaching techniques but also change in teaching perspectives (Aoki, 2008). But in the non-western society, the benchmarks for good behaviors are the principles of total obedience, and the unquestioning mind is sustained with the belief that teachers cannot do wrong. That's

why such Western concept in ELT is not without problem in non-Western cultural context.

\section{Research findings on learner autonomy in ELT in Asian context}

The concept of learner autonomy in language learning is considered a Western construct or Western origin. Consequently, it has led some thinkers to view it as a cultural-imperialist imposition on nonWestern cultures (Smith, 2002, p. 8). Learner autonomy has now become a global educational issue, with a number of recent publications focusing on the status and challenges of learner autonomy in different educational cultures in the world (Benson, 2007, p. 25). While the first few decades the concept of learner autonomy in language learning was dominated by European initiatives. Later, it went on to gain traction in other parts of the world and got spread to Asia in the 1990s as a prominent concept in international conferences that was held in cities like Hong Kong, Bangkok and Tokyo (Smith, 2008).

Especially, researchers have explored the relationship between learner autonomy and language proficiency. They have found that autonomous learners are the learners of high language proficiency and different high-achievement students apply different autonomous strategies (Dafei, 2007). Autonomy is an essential characteristic for a good language learner. Especially for those who learn a language as a foreign language do not have the opportunity to hear or use the language in the real world. It is their own responsibility to create and be in environments where the target language is used (Bayat, 2008).

The students having low autonomy perception have more negative classroom behaviors compared to the students having high autonomy. The students who have high autonomy perception have more positive classroom behaviors compared to 
the students having lower autonomy perception. It also appears that most of the students are ready to learn autonomously and they are good at using opportunities in different learning environments. Knowing about how autonomous learners behave may help them improve their autonomous learning skills (Bayat, 2008). But there is some sort of mismatch between theoretical and pedagogical assumptions of learner autonomy that's why little autonomy is possible in Asian context (Aoki, 2008). If this is the situation how we practice autonomy oriented activities in the classroom.

It is reported that some aspects of Chinese culture can impede learner autonomy however teachers still foster learner autonomy by using appropriate teaching strategies (Ho \& Crookall, 1995, as cited in Neupane, 2010). In his research about learner autonomy in Nepalese cultural context, Joshi (2011) found that it is teachers' responsibility to make them autonomous with the content and process of learning. Students also agreed that a lot of learning can be done without a teacher (p. 23). It can support for the necessity of implementation of autonomy in Nepalese context. Smith (2006) also informs that students from various East Asian Countries are able to be autonomous with the pressure to be autonomous. Learners perceive themselves as being capable of more involved in their own learning (Johnston et al., 2014). So, it is very important for teachers to set about unconditioning themselves and also help the children to be free of conditioning. Knowing the conditioning influence of parents, of tradition, of society, the teacher must encourage the children not thoughtlessly to accept, but always to question, investigate and be in revolt (Krishnamurti, 1987).

Being conscious about the influence of learners' culture, Khaki (2013) has researched about Iranian learners on English as first language learning. He suggests that culture is a set of rules that have to be known to be able to live in a society because certain cultural traits might either facilitate or inhibit learner autonomy. He also suggests that there is no significant difference between learners from China, Taiwan and Hongkong. Only individual differences do exist. The study highlights problems in the implementation of practices connected with the development of learner autonomy in a variety of contexts. If autonomy is developed and enhanced in learners, they will achieve their learning goals and if they will achieve their learning goals, they will have a positive attitude toward their future learning. Therefore, developing and enhancing learner autonomy would be considered as a guarantee for learner's present and future success (Khaki, 2013). Holliday (2005) says that the pupils' choice of learning style was in itself autonomous even though it would not be seen as autonomous within the dominant educational ideology.

Aliya, a teacher explains that students from cities and well-off families are autonomous and they take responsibility for their own learning but rural students mostly girls never look at the teachers to show respect. Such students have to be taught to be autonomous (Holiday, 2005). There is particular social group will have problems with autonomy because of previous schooling experience and expectations (ibid). For this, research has approached the notion of fostering learner autonomy in educational contexts, saying that learners could be trained differently to be autonomous. Johnston et al. (2013) updates the example that East Asian autonomy is not proactive because students' knowledge is not considered as the source of learning. 
As one of the purposes of learner autonomy is to develop learners to be critical citizens capable of independent participation in democratic processes, it has been discussed whether learner autonomy is exclusively a Western goal that would be unattainable in countries and cultures with different political systems and paradigms. But it has been pointed out that autonomy is a common ideal even in non-Western cultures (Littlewood, 1999, p.12). Furthermore, it is evident that cultural differences, however great they may seem, generally do not override universal human needs such as the need to experience autonomy and develop as an autonomous being. Learner autonomy is an appropriate $\&$ potential in education goal even in Taiwan, China, Syria (Smith, 2008). Learner autonomy is therefore a universally valid goal, although approaches to promote it have shown to vary according to cultural context (Palfreyman \& Smith, 2003, p.7).

As we know that everything has positive and negative aspects. So is the case in learner autonomy to this era. It is said that concept of learner-autonomy is laden with cultural values of West and it is inappropriate to expect full autonomy not only of Cambodians who are dependent and authority-oriented but of people from many countries between Morocco and Japan. They find it difficult to accept the individual responsibility and freedom derived from Western values (Jones, 1995, as cited in Holliday, 2005). In this sense, cultural bias in more self-directed learning has originated in Western cultures and does not fit with non-western philosophies. But the teacher proposes a definite need to bring Asian students round with the help of Asian teachers who have studied in the West to mediate between cultures to find a way forward (Hedge, 2000, as cited in Holliday, 2005). Because one size can't fit all and each culture has the right to develop what is best for its own particular culture
(Witty et al., 1998, as cited in Nguyen et al., 2006).

In order to address such diversity and cultural problem, it is better to build trust with them and become familiar with their culture building intimate relationship so that teachers can talk with question technique and provide feedback to establish positive home-school relationship. It is not better to generalize the cultural practice of a community to other community without recognizing their distinctive cultural dimension because adopting policies, theories and practices across cultures may create problems (ibid). This shows the importance of learner autonomy but it is not out of question to its implication in Asian cultural context.

\section{Learner autonomy and students" learning in African context: Research findings}

Pedagogy of autonomy is considered the first and foremost as a pragmatic strategy to promote learning in African context. They seem to provide evidence of appropriateness of a particular form of autonomy-related practice in an African school setting (Kuchah \& Smith, 2011). It is contrast with the argument of Sonaiya's (2002) who says that pedagogies for engaging with the practice of learner autonomy are inappropriate in African contexts due to large class, lack of resources, technology, multilingual backgrounds of many sub-Saharan classrooms, to name a few. It is particularly difficult to sustain when we consider such contextual factors. It makes difficult for teachers to claim complete responsibility for what learners learn.

In the same way, Kuchah's experience in teaching is related to learner autonomy. His innovative practice was developed as a pragmatic response to the learner 
autonomy that provides a rare insight into the realities of the different cultural context where most English teaching goes on in the world (Kuchah \& Smith, 2011). Beyond this, it presents pedagogy of autonomy as an innovative method to address problem in different cultural context.

\section{Conclusion}

The paper has analyzed the concept of learner autonomy as a western hegemony for non-western cultural context in English language teaching. Based the above discussion, it concludes that the concept of learner autonomy was developed in the western countries with the perspectives of schooling their children developing autonomy friendly culture in the society. They assumed to extend its perspective in school education system to prepare learner as an independent person in the society. In non-Western cultural context, there is lack of integration with the perspectives of society and education for schooling their children. It is because parents set up the norms and values for their children whereas formal system education is based on Western trend that is considered a key to transform the society. It shows that the education system and its transformation is just opposite in the Western countries. It is thus learner autonomy is considered as a western hegemony in English language teaching however it enhances learning competency of students for non-Western cultural context. From this perspective, learner autonomy needs learning friendly cultural context especially for learning English language though it is considered cross-culturally valid phenomena.

It also concludes that autonomy friendly culture and environment of Western countries should not generalize in ELT to non-western cultural context where there is lack of autonomy friendly culture, environment, technology, facilities and classroom situation for learners to develop the competency of learning to learn. It is thus classroom oriented, culture oriented and facility oriented autonomy is considered the best way in non-Western countries to prepare autonomous learners to learn English language themselves. It comes under the philosophical assumption of constructivist epistemology and theoretical perspective of post method pedagogy and the pedagogy of autonomy. It allows learners to experience learning by pursuing, processing and obtaining knowledge through self learning process to get the mastery of own learning in which teachers try their best to develop autonomy friendly culture and environment in English language teaching to enhance students' learning as far as possible. It also concludes that it is better to consider the socio-cultural context along with the learning theories and learning perspectives that help them to reach a new level of learner autonomy to practice in English language teaching to enhance students learning competency based on local demand of non-Western cultural context.

\section{References}

Anderson, J. (2011). Autonomy, agency and the self. In B. Fultner (Eds.). Jurgen Habermas: Key concepts (pp. 91-115). New Delhi: Rawat Publications.

Aoki, N. (2008). Teacher stories to improve theories of learners/teacher autonomy. Independence, 43,15-17. Retrieved from: http:// learner autonomy.org/aoki 2008. pdf.

Barkema, H.G., Chen, X-P., George, G. Luo, Y., \& Tsui,A. (2015). West meets East: New concepts and theories. Academy of Management Journal, 58(2), 460-479.

Bayat, U. A. O. (2008). The relationship between autonomy perception and classroom behaviors of English language learners (Unpublished doctoral thesis). School of Education, Bilkent University, Turkey. 
Benson, P. (2001). Teaching and researching autonomy in language learning. London: Longman.

Benson, P. (2007). Autonomy in language teaching and learning. State of the Art Article, Language Teaching, 40 (1), 2140 .

Blin, F. (2005). CALL and the development of learner autonomy: An activity theoretical study (Unpublished doctoral thesis). Institute of Educational Technology, The Open University, Paris X-Nanterre, France.

Chang, V., Scott, S. \& Decker, C. (2009). Developing helping skills: A step-by-step approach. USA: Brooks

Dafei, D. (2007). An exploration of the relationship between learner autonomy and English proficiency. Asian EFL Journal Professional Teaching Articles, 7 (1). Retrieved from w w w . asian-efl-journal.com / pta_Nov_07_dd.pdf?origin=publication

Dardjowidjojo, S. (2001). Cultural constrains in the implication of learner autonomy: The case in Indonesia. Journal of Southeast Asian Education, 2(2), 309-322.

Dang, T. T. (2010). Learner autonomy in EFL studies in Vietnam: A discussion from socio- cultural perspective. English Language Teaching, 3(2), 3-9.

Dewey, J. (1966). Democracy and education. New York, NY: Free Press.

Fleischer, L.E. (2013). Counter-hegemonic teaching. New York, NY: Sense Publishers.

Gramsci. A (n.d).Theory: Cultural hegemony. http://beautifultrouble. org/theory/cultural-hegemony/
Halliday, A. (2005). The struggle to teach English as an international language. New York, NY: Oxford.

Holec, H. (1981). Autonomy and foreign language learning. Oxford: Pergamon.

Johnston, C., Aliponga, J., Koshiyama, Y., Ries, T., \& Rush, T. (2014). Learner autonomy in university English classes. In Nozomu Sonda \& A. Krause (Eds.), JALT 2013 Conference Proceedings. Tokyo: JALT.

Joshi, K. R. (2011). Learner perceptions and teacher beliefs about learner autonomy in language learning.Journal of NELTA, 16(1-2). 13-29.

Khaki, S. (2013). The relationship between learner autonomy and willingness to communicate (WTC) in Iranian EFL learners. International Journal of Applied Linguistics E English Literature, 2(5), 97109.

Kincheloe, J. (2004). Iran and American miseducation: Cover-ups, distortions, and omissions. In J. Kincheloe \& S. Steinberg (Eds.). The miseducation of the West: Constructing Islam. NY: Greenwood.

Kincheloe, J. (2008). Critical pedagogy and knowledge wars of the twenty-first century. International Journal of Critical Pedagogy, 1(1), 1-22.

Knaldre, H. (2015). Learner autonomy promotion: A qualitative document analysis of two Norwegian national curricula (Unpublished master' thesis). School of Education, Bergen University, Norway.

Koirala, B. N. (2011). Alternative thinking in education. Kathmandu: Afo Publication.

Krishnamurti, J. (1987). Life ahead. USA: Krishnamurti Foundation of America. 
Kuchah, K., \& Smith, R. (2011). Pedagogy of autonomy for difficult circumstances: from practice to principles.International Journal of Innovation in Language Learning and Teaching, 5(2), 119-140.

Kumaravadivelu, B. (2002). Beyond methods: Macrostrategies for language teaching. New Haven, CT: Yale University Press.

Kumaravadivelu, B. (2003). A postmethod perspective on English language teaching. World Englishes, 22(4), 539550 .

Lamichhane, S. P., \& Wagley, M. P. (2008). Post-modernism and Nepal's education. Journal of Education and Research, 1(1), 9-12.

Littlewood, W. (1999). Defining and developing autonomy in East Asian contexts. Applied Linguistics,20, 71-94.

Neupane, M. (2010). Learner autonomy: Concept and considerations. NELTA Journal, 15(1-2), 114-120.

Nguyen, P. M., Terlouw, C., \& Pilot, A. (2006). Culturally appropriate pedagogy: The case of group learning in a Confucian heritage culture context. Intercultural Education, 17(1), 1-19.

Palfreyman, D., \& Smith, R. C. (2003). Learner autonomy across cultures: Language education perspectives. New York: Palgrave Macmillan.

Pokhrel, S. (2013).Classroom practices of public school teachers in Kathmandu. (Unpublished thesis of Master in Philosophy in Education of Tribhuvan University)

Poudel Gharti, B.U. (2006). Learner centered teaching: Teacher perceptions and practices. Unpublished Thesis of Master in Philosophy in Education. Kathmandu University

Smith, R. (2008). Key concepts in ELT: Learner autonomy. ELT Journal, 62(4), 395-397. doi:10.1093/elt/ccn038

Smith, R. C. (2006). Developing teacherlearner autonomy: Constraints and opportunities in pre service training. In L. Bobb-Wolf \& J. L. Vera Batista (Eds.), Proceedings of the Canarian conference on developing autonomy in the FL classroom. La Laguna: University of La Laguna.

Smith, R. (2002). Autonomy, context, and appropriate methodology. In F. Vieira, M. A., Moreira, I. Barbosa, \& M. Paiva (Eds.), Pedagogy for autonomy and English learning: Proceedings of the 1st Conference of the Working Group Pedagogy for Autonomy. Braga: Universidad do Minho.

Sonaiya, R. (2002). Autonomous language learning in Africa: A mismatch of cultural assumptions. Language, Culture and Curriculum, 15(2), 106-116.

Stefanou, C. R., Perencevich, K. C., Dicintio, M., \& Turner, J.C. (2004). Supporting autonomy in the classroom: Ways teachers encourage student decision making and ownership. Educational Psychologist, 39(2), 97-110.

Zhuang, J. (2010). The changing role of teachers in the development of learner autonomy based on a survey of English dorm activity. Retrieved from www.academypublication. com/ issues/past/jltr /vol01/05/07.pdf

The author: Sarmila Pokhrel, PhD student in Kathmandu University, has been teaching English in secondary level for around 20 years. Involved in various English teaching related research activities throughout her teaching profession, her major area of interest is learner autonomy She has

Journal of NELTA, Vol 21 No. 1äready published a paper about the ${ }^{139}$ concept and methods related to learner autonomy. 